\title{
Estimation of stature from dimensions of hands and feet in a South Indian Population
}

\author{
Bharath Shetty $^{1}$, M. Deepak ${ }^{2 *}$, Francis N.P. Monteiro ${ }^{3}$, Karen Prajwal Castelino ${ }^{4}$, Arun Pincho Xavier ${ }^{5}$ \\ 1,2,4,5 Assistant Professor, ${ }^{3}$ Professor and HOD, Dept. of Forensic Medicine \& Toxicology, ${ }^{\mathbf{1}}$ KVG Medical College, Kurunjibag, Sullia, \\ Karnataka, ${ }^{2}$ Shimoga Institute of Medical Sciences, Shivamogga, Karnataka, ${ }^{3}$ A.J. Institute of Medical Sciences \& Research Centre, \\ Mangalore, Karnataka, ${ }^{4}$ Father Muller Medical College, Mangalore, Karnataka, ${ }^{5}$ Mookambika Institute of Medical Sciences,
} Kulasekharam, Tamil Nadu, India

*Corresponding Author: M. Deepak

Email: deepakforensic@gmail.com

\begin{abstract}
Introduction: There is an established relationship between stature and various body parts like head, trunk, upper and lower extremity. This allows forensic expert to estimate stature from different parts of the body. Many studies have been conducted in many ethnic groups to estimate stature from hand and foot dimensions.

Objectives: The purpose of this cross sectional study is to estimate stature from hand and foot dimensions in South Indian origin student population.

Materials and Methods: Four anthropometric measurements viz. hand length, hand breadth, foot length and foot breadth were taken independently on the left and right side of each individual. Besides these, stature and weight of each subject were also recorded. Only right handed subjects were included in the present study.

Results: In this cross sectional study of south Indian population, hands and feet dimensions were utilized to predict the stature of a person. The study includes 398 persons (149 males and 149 females) aged between 17 and 30 years. The average stature among males was $167.6 \pm$ 6.2 and ranged between $151 \mathrm{~cm}$ and $167.6 \mathrm{~cm}$. The average stature among females was $152.5 \pm 4.9$ and ranged between $142 \mathrm{~cm}$ and $165 \mathrm{~cm}$. Males have larger hand and foot dimensions than females. The sex differences are highly significant in left foot length, right foot length, left hand breadth and right hand breadth; and significant in right foot breadth. All the parameters of hands and feet showed statistically significant positive correlation with stature in the present study and thus can be successfully utilized for stature estimation.

Conclusion: The present cross sectional study emphasizes the utility of dimension of hands and feet in estimating stature by law enforcement agencies and forensic scientists, especially in mutilated and dismembered human remains.
\end{abstract}

Keywords: Foot breadth, Foot length, Hand Breadth, Hand length, Stature.

\section{Introduction}

Anthropometric technique commonly used by anthropologists and adopted by medical scientists has been employed to estimate stature for over a hundred years. ${ }^{1}$ In the last half of the $20^{\text {th }}$ century, studies have been more vigorous when skeletal collections have been assembled in many parts of the world. ${ }^{2}$ The stature of an individual is an inherent characteristic; its estimate is considered to be an important assessment in the identification of unknown human remains. There is an established relationship between stature and various body parts like head, trunk, upper and lower extremities. This allows a forensic expert to estimate stature from different parts of the body. It is common to find the peripheral parts of the body such as hand and foot in explosions, aircraft and railway accidents. Many studies have been conducted in different ethnic groups to estimate stature from hand and foot dimensions. ${ }^{3-6}$ There is paucity of such studies in south Indian population. An attempt has been made in the present study to estimate stature from hand and foot dimensions of south Indians and to conduct a comparative study between them.

\section{Materials and Methods}

Materials for this cross sectional study consists of all students and staff of South Indian origin of A.J. Institute of Medical Sciences \& Research Centre, Mangalore, Karnataka who are willing to participate in the study comprising of both the genders in the age group of 17-30 years belonging to various parts of South India (Karnataka, Kerala, Tamil Nadu, Andhra Pradesh \& Union territories of Lakshadweep \& Pondicherry) during the period from September, 2012 to September, 2014. Due permission was taken from Institutional Ethics Committee of A.J. institute of Medical Sciences \& Research Centre, Mangalore for the conduct of the study.

Methods for the study consisted of measuring various hand and foot dimensions of these students. Four anthropometric measurements viz. hand length, hand breadth, foot length and foot breadth were taken independently on the left and right side of each individual. Besides these, stature and weight of each subject were also recorded. Only right handed subjects were included in the present study. All the measurements were taken in a well lighted room. Before taking the measurements, each subject was asked to remove the shoes. The measurements were taken by one observer (AS) in order to avoid inter-observer error.

Diurnal variations have been reported in the stature of an individual ${ }^{7}$ thus, all measurements were taken during afternoon hours to avoid diurnal variations, if any. The measurements were taken using standard anthropometric instruments in centimeters to the nearest millimeter. All the measurements are recorded on a prestructured proforma.

Stature is measured as the vertical distance between the vertex and the floor, where the vertex is the highest point on the head when the head is held in Frankfurt Horizontal (FH) 
plane. Hand length is projected distance between the points inter-stylion (middle point of the line connecting the point stylion radiale, i.e., the most distal point on the styloid process of radius and stylion ulnare, i.e., the most distal point on the styloid process of ulna and the tip of the third finger using Digital pointed Vernier calipers). Hand breadth is the distance between the most prominent point, outside of the lower epiphyses of the 2nd metacarpal (metacarpal radiale., i.e., point most medially projected on the head of the 2nd metacarpal when the hand is stretched) to the most prominent inside point of the lower epiphyses (metacarpal ulnare, i.e., Metacarpal- ulnare: It is the point projecting most laterally from the head of the 5th metacarpal) of the 5th metacarpal using Digital pointed Vernier calipers. Foot length is the distance from the most backward and prominent part of the heel (pternion) and the most distal part of the longest toe of the foot (acropodian). Foot breadth is measured perpendicular to the long axis with sliding calipers as a straight distance between the metatarsale fibulare and metatarsale tibiale with the foot in a fully stretched position with a Digital pointed Vernier calipers. The foot length of each individual was measured with a Digital pointed Vernier calipers as a straight distance between the pternion and acropodian with the subject standing upright with equal pressure on both the feet.

Base line data will be represented using tables. Statistical analysis was carried out using IBM SPSS Statistics (IBM Inc., version 17 for Windows) software package to calculate linear and multiple regression equations and compute multiplication factor. Multiplication factors for hand and foot dimensions were calculated by dividing the stature of an individual by hand and foot dimensions, respectively for each subject in males and females and dividing the sum by the sample size. Pearson's correlation coefficient was calculated to establish the correlation between the stature and the hand and foot dimensions. Paired sample t-test was performed to find the right and left side differences in hand and foot dimensions among males and females. The significance of results was tested using Student"s t-test. p-Value of less than 0.01 was considered as significant.

\section{Results}

The present study consists of a cross sectional sample of 298 students and staffs (149 males and 149 females) of south Indian origin from A. J. Institute of Medical Sciences and Research Centre, Mangalore, ranging in age from 17 to 30 years belonging to various regions of south India.

The average stature among males was $167.6 \pm 6.2$ and ranged from $151 \mathrm{~cm}$ and $167.6 \mathrm{~cm}$. The average stature among females was $152.5 \pm 4.9$ and ranged between $142 \mathrm{~cm}$ and $165 \mathrm{~cm}$. All the values of all the measurements in case of males are higher than females. These sex differences are highly significant $(p<0.001)$ in left foot length, right foot length, left hand breadth and right hand breadth; and significant $(p<0.01)$ in right foot breadth. The mean difference, standard difference and $t$ values are higher in cases of males and are statistically significant. $(\mathrm{p}<0.01)$ No significant statistical differences are found in the measurements of hand length, hand breadth, foot length and foot breadth in both sides.

The comparison of stature with other anthropometric measurements in males, observed that, correlation is significant at the 0.01 level (2-tail) in the left hand length measurement and at 0.05 level (2-tail) in the right hand length, left hand breadth and right foot breadth measurements. It is observed that, correlation is significant at the 0.01 level (2-tail) in the left hand length measurement and at 0.05 level (2-tail) in the right hand length measurements.

Linear regression generally accepted in the form of $\mathrm{y}=\mathrm{a}+\mathrm{bx}$, where, $\mathrm{y}^{\prime \prime}$ is the value to be estimated, which is stature; „a" is the regression coefficient of the dependent variable, ,,${ }^{\prime \prime}$ is the regression coefficient of the independent variable that is hand length, hand breadth, foot length, and foot breadth of both the sides and „X" is the measurement of hand or feet. Table 8 presents the linear regression equations for various parameters of hand and feet derived by the statistical analysis in males.

Table 1 exhibits linear regression equations predicting stature using various parameters of hands and feet in males. The equation also presents standard error of estimate (SEE). The SEE predicts the deviations of estimated stature from actual stature. It ranges between \pm 6.04 to \pm 6.16 in relation to parameters of hand and \pm 6.15 to \pm 7.15 in relation to parameters of feet. A low value indicates the greater reliability in the estimated stature. Left hand length and left foot breadth exhibits a lower value in males and gives better reliability in prediction of stature.

Table 1: Linear regression equations derived by the statistical analysis in males

\begin{tabular}{|c|c|}
\hline Stature $=135.40+1.687(\mathrm{RHL})$ & SEE \pm 6.116 \\
\hline Stature $=129.81+2.015(\mathrm{LHL})$ & $\mathrm{SEE} \pm 6.038$ \\
\hline Stature $=155.64+1.465(\mathrm{RHB})$ & $\mathrm{SEE} \pm 6.158$ \\
\hline Stature $=151.67+1.984(\mathrm{LHB})$ & $\mathrm{SEE} \pm 6.129$ \\
\hline Stature $=180.48-0.499(\mathrm{LFL})$ & $\mathrm{SEE} \pm 6.211$ \\
\hline Stature $=170.12-0.094(\mathrm{RFL})$ & $\mathrm{SEE} \pm 6.232$ \\
\hline Stature $=153.24+1.548(\mathrm{LFB})$ & $\mathrm{SEE} \pm 6.154$ \\
\hline Stature $=150.79+1.789(\mathrm{RFB})$ & $\mathrm{SEE} \pm 7.146$ \\
\hline
\end{tabular}

$(\mathrm{RHL}=$ Right Hand Length; RHB $=$ Right Hand Breadth; LHL= Left Hand Length; LHB= Left Hand Breadth; RFL= Right Foot Length; RFB= Right Foot Breadth; LFL= Left Foot Length; LFB= Left Foot Breadth)

Table 2 exhibits linear regression equations predicting stature using various parameters of hands and feet in females. The SEE ranges between \pm 4.76 to \pm 4.87 in relation to parameters of hand and \pm 4.88 to \pm 4.89 in relation to parameters of feet. Left hand length, right foot length and left foot breadth exhibits a lower value in males and gives better reliability in prediction of stature. 
Table 2: Linear regression equations derived by the statistical analysis in females

\begin{tabular}{|c|c|}
\hline Stature $=125.35+1.53(\mathrm{RHL})$ & $\mathrm{SEE} \pm 4.789$ \\
\hline Stature $=128.56+1.38(\mathrm{LHL})$ & $\mathrm{SEE} \pm 4.760$ \\
\hline Stature $=157.90-0.73(\mathrm{RHB})$ & $\mathrm{SEE} \pm 4.874$ \\
\hline Stature $=158.14-0.79(\mathrm{LHB})$ & $\mathrm{SEE} \pm 4.870$ \\
\hline Stature $=152.83-0.02(\mathrm{LFL})$ & $\mathrm{SEE} \pm 4.893$ \\
\hline Stature $=158.14-0.23(\mathrm{RFL})$ & $\mathrm{SEE} \pm 4.883$ \\
\hline Stature $=148.02+0.50(\mathrm{LFB})$ & $\mathrm{SEE} \pm 4.883$ \\
\hline Stature $=152.12+0.04(\mathrm{RFB})$ & $\mathrm{SEE} \pm 4.893$ \\
\hline
\end{tabular}

(RHL= Right Hand Length; RHB= Right Hand Breadth; LHL= Left Hand Length; LHB= Left Hand Breadth; RFL= Right Foot Length; RFB= Right Foot Breadth; LFL= Left Foot Length; LFB= Left Foot Breadth)

Multiple regression was calculated similarly to the linear regression but here the independent variables are two or more, like hand length, hand breadth, foot length, and foot breadth. Table 3 illustrates the multiple regression equations for estimation of stature by using hand and feet measurement on the left side for males and Table 4 illustrates the multiple regression equations for estimation of stature by using hand and feet measurement on the right side for males. The range of standard errors of estimation in case of multiple regression is smaller than that of linear regression obtained, this reveals the fact that the use of multiple parameters is superior than use of single parameter. And hence the accuracy in estimation is much better with a smaller range of error in estimation.

In Table 3 equations are computed using left side of the male population studied. Equation number 1 where all the parameters are used to derive the equations, in $2^{\text {nd }}$ equation only the length and breadth of hands are used and while in equation number 3 , the measurements of foot is used.

Table 3: Multiple regression equations for estimation of stature by using hand and feet measurement on the left side for males

\begin{tabular}{|l|l|c|c|}
\hline \multicolumn{4}{|c|}{ Left side } \\
\hline 1 & Stature & $147.91+2.21(\mathrm{HL})+0 . .38(\mathrm{HB})-1.07(\mathrm{FL})+0.30(\mathrm{FB})$ & \pm 5.997 \\
\hline 2 & Stature & $129.74+1.74(\mathrm{HL})+0.66(\mathrm{HB})$ & \pm 6.050 \\
\hline 3 & Stature & $167.20-0.57(\mathrm{FL})+1.61(\mathrm{FB})$ & \pm 6.147 \\
\hline
\end{tabular}

(HL=Hand Length; HB= Hand Breadth; FL= Foot Length; FB= Foot Breadth)

In Table 4 equations are computed using right side of the male population studied. Equation number 1 where all the parameters are used to derive the equations, in $2^{\text {nd }}$ equation only the length and breadth of hands are used and while in equation number 3 , the measurements of foot is used.

Table 4: Multiple regression equations for estimation of stature by using hand and feet measurement on the right side for males

\begin{tabular}{|l|c|c|}
\hline \multicolumn{3}{|c|}{ Right side } \\
\hline Stature & $146.37+1.51(\mathrm{HL})-0.06(\mathrm{HB})-0.67(\mathrm{FL})+1.13(\mathrm{FB})$ & \pm 6.116 \\
\hline Stature & $136.97+1.41(\mathrm{HL})+0.46(\mathrm{HB})$ & \pm 6.133 \\
\hline Stature & $158.74-0.33(\mathrm{FL})+1.88(\mathrm{FB})$ & \pm 6.130 \\
\hline
\end{tabular}

(HL=Hand Length; HB= Hand Breadth; FL= Foot Length; FB= Foot Breadth)

Table 5 illustrates the multiple regression equations for estimation of stature by using hand and feet measurement on the left side for females, and Table 6 illustrates the multiple regression equations for estimation of stature by using hand and feet measurement on the right side for females.

In Table 5 equations are computed using left side of the female population studied. Equation number 1 where all the parameters are used to derive the equations, in $2^{\text {nd }}$ equation only the length and breadth of hands are used and while in equation number 3 , the measurements of foot is used.

Table 5: Multiple regression equations for estimation of stature by using hand and feet measurements on the left side for females

\begin{tabular}{|c|c|c|c|}
\hline \multicolumn{4}{|c|}{ Left side } \\
\hline 1 & Stature & $120.47+3.32(\mathrm{HL})-3.56(\mathrm{HB})-0.22(\mathrm{FL})+0.62(\mathrm{FB})$ & \pm 4.491 \\
\hline 2 & Stature & $124.13+3.19(\mathrm{HL})-3.72(\mathrm{HB})$ & \pm 4.481 \\
\hline 3 & Stature & $148.63+0.51(\mathrm{FB})-0.03(\mathrm{FL})$ & \pm 4.900 \\
\hline
\end{tabular}

(HL=Hand Length; $\mathrm{HB}=$ Hand Breadth; FL= Foot Length; FB= Foot Breadth) 
In Table 6 equations are computed using right side of the female population studied. Equation number 1 where all the parameters are used to derive the equations, in $2^{\text {nd }}$ equation only the length and breadth of hands are used and while in equation number 3 , the measurements of foot is used.

Table 6: Multiple regression equations for estimation of stature by using hand and feet measurements on the right side for females

\begin{tabular}{|l|l|c|c|}
\hline \multicolumn{4}{|c|}{ Right side } \\
\hline 1 & Stature & $160.63+2.29(\mathrm{HL})-1.30(\mathrm{HB})-0.36(\mathrm{FL})-1.64(\mathrm{FB})$ & \pm 6.128 \\
\hline 2 & Stature & $147.13+1.90(\mathrm{HL})-1.76(\mathrm{HB})$ & \pm 6.185 \\
\hline 3 & Stature & $183.60-0.08(\mathrm{FL})-1.54(\mathrm{FB})$ & \pm 6.176 \\
\hline
\end{tabular}

(HL=Hand Length; $\mathrm{HB}=$ Hand Breadth; FL= Foot Length; FB= Foot Breadth)

Comparison of actual stature and stature estimated from measurements of hands and feet are shown in Table 7. Estimation was calculated using the linear regression equations obtained by the study. The maximum, minimum and mean values of independent variables of each parameters are considered as represented in the table number 1 and 2, and the estimated stature is calculated for each parameters used in this study for both females and males.

Table 7: Comparison of actual stature and estimated stature from measurements of hands and feet

\begin{tabular}{|c|c|c|c|c|c|c|}
\hline $\begin{array}{c}\text { Estimated stature } \\
\text { using regression } \\
\text { equation for }\end{array}$ & $\begin{array}{c}\text { Minimum } \\
\text { estimated } \\
\text { stature }\end{array}$ & $\begin{array}{c}\text { Maximum } \\
\text { estimated } \\
\text { stature }\end{array}$ & $\begin{array}{c}\text { Mean } \\
\text { estimated } \\
\text { stature }\end{array}$ & $\begin{array}{c}\text { Maximum } \\
\text { estimated } \\
\text { stature }\end{array}$ & $\begin{array}{c}\text { Maximum } \\
\text { estimated } \\
\text { stature }\end{array}$ & $\begin{array}{c}\text { Mean } \\
\text { estimated } \\
\text { stature }\end{array}$ \\
\hline Right hand length & 164.73 & 171.19 & 167.72 & 150.31 & 156.41 & 152.44 \\
\hline Left hand length & 163.84 & 172.34 & 167.63 & 150.25 & 157.25 & 152.45 \\
\hline Right hand breadth & 165.22 & 169.10 & 167.63 & 151.34 & 153.34 & 152.48 \\
\hline Left hand Breadth & 164.92 & 170.12 & 167.64 & 151.13 & 153.37 & 152.49 \\
\hline Right foot length & 167.50 & 168.05 & 167.70 & 151.67 & 153.30 & 152.64 \\
\hline left foot length & 168.78 & 167.39 & 166.52 & 151.41 & 152.52 & 152.46 \\
\hline Right foot breadth & 164.74 & 169.54 & 167.43 & 152.40 & 152.51 & 152.47 \\
\hline Left foot Breadth & 165.61 & 170.19 & 167.83 & 151.79 & 153.22 & 152.59 \\
\hline Actual stature & 151 & 183 & 167.65 & 142 & 165 & 152.47 \\
\hline
\end{tabular}

\section{Discussion}

Stature estimation is an important factor in identification of commingled remains in forensic examinations. It can be achieved by anatomical and mathematical method. ${ }^{3,8,9}$ The anatomic method is generally preferred over mathematical method when the complete skeleton or cadaver is available. The anatomical method involves reconstruction of stature by measuring and adding together the lengths of a series of adjacent skeletal elements from the skull through the foot. The development of the anatomical method is attributed to Fully. ${ }^{7}$ Anatomical method provides best approximation of stature when applicable to skeleton or cadaver. ${ }^{9-17}$ However, when mutilated remains and skeletal parts are referred for personal identification in forensic examinations, the forensic experts have to rely upon mathematical methods for stature estimation. Mathematical methods make use of the measurements of one or more bones or body parts to determine stature. Distinct advantage of mathematical methods is that a single body part can be used to estimate the living stature of an individual. The main disadvantage of the mathematical method however, is that the stature estimated using these methods is not absolutely accurate owing to wide variations in dimensions of body parts, bones and statute in a population group, necessitating different formulae are required for different population groups, different bones or body parts. ${ }^{18}$ Standard error of estimate thus needs to be considered giving a possible range of stature from a given bone/body part. Mathematical methods employed in stature estimation include multiplication factor and regression analysis. Forensic significance of these mathematical methods is based on the principle that there is a high linear correlation between an individual"s stature and the body part or bone length.

Studies have shown that hand dimensions vary in different races. Nigerian female hand was found to be wider and shorter than that of their foreign counterparts. ${ }^{19} \mathrm{~A}$ significant difference was found in hand lengths of females among Indians, west Europeans and natives of West Indies, while no difference was found in hand breadth. ${ }^{20}$

Our study reveals that mean values of hands and feet measurement were higher in males when compared to females among all the parameters. This is in concurrence with other studies across the globe. ${ }^{5,6,21}$ This may be attributable to the fact that males are genetically taller than females, and age of puberty being two years later in males as compared to females give them additional time for 
growth. ${ }^{6,21}$ This suggests that the formula for one sex cannot be applied to estimate stature for other sex.

All the parameters of hands and feet showed statistically significant positive correlation with stature in the present study and thus can be successfully utilized for stature estimation. Left hand length is very highly significant among both the genders and showing higher degree of correlation with stature. Next in order of significance is right hand length in both the genders. Thus among both the genders left hand length is the best parameter to estimate stature in both the genders. The relatively low standard estimate of error for the hand length in males $( \pm 6.038)$ and in females $( \pm 4.760)$ ensures better precision in stature estimation. The presence of a positive linearity between the study variables and the stature facilitates formulation of regression equations which can be successfully utilized for stature estimation in south Indian population.

Various studies around the globe in relation to estimation of stature from foot lengths 4,21, 22, 23,24,25,26,27 depicts a positive correlation between the foot length and stature, which ranged between 0.56 to 0.86 and 0.5 to 0.8 in males and females respectively, illustrating the importance of foot length in stature estimation. The value of correlation co-efficient as obtained in the present study was - for males and -0.06 for females. This is lower as compared to all the other studies. This low value of Pearson "s correlation may be attributable to differences genetic and other environmental factors. Although several other Indian studies have been conducted for stature estimation from foot measurements, the present findings are not comparable to them as those studies are not conducted in similar population. ${ }^{4,21,23,25,28,29,30}$ Due to strong influence of genetic and environmental factors on the height of the individual, similarity of the study population is vital in formulating regression equations.

Pearson"s correlation coefficients of males and females for estimation of stature from hand length was almost identical in the present study ( 0.24 in males and 0.22 in females). Similar study across the nation reveals the negligible gender difference. ${ }^{21,28,29}$

The Pearson"s correlation coefficients obtained for these parameters for both thegenders in the present study are slightly lower but comparable to other studies around the globe. ${ }^{21,31}$ The observations of the present study suggest that these parameters can be utilized to formulate equations to predict stature.

\section{Conclusion}

The present study emphasizes the utility of dimension of hands and feet in estimating stature by law enforcement agencies and forensic scientists, especially in mutilated and dismembered human remains. The care must be taken to adopt population specific and gender specific formulae to ward off the influence of genetic and environmental factors like climate, nutrition etc. . $^{6,32,33}$

\section{Source of funding}

None.

\section{Conflict of interest}

None.

\section{References}

1. Pearson K. Mathematical contributions to the theory of evolution: On the reconstruction of the stature of prehistoric races. Philos Trans $R$ Soc Lond 1899;192:169-244.

2. Dupertuis $\mathrm{CW}$, Hadden J. On the reconstruction of staturefrom long bones. Am J Phys Anthropol 1951; 9:15-54.

3. Ozaslan A, Koc S, Ozaslan I, Tugcu H. Estimation of stature from upper extremity. Mil Med 2006;171:288-91.

4. Sanli SG, Kizilkanat ED, Boyan N, Ozsahin ET, Bozkir MG, Soames R, et al. Stature estimation based on hand length and foot length. Clin Anat 2005; 18:589-96.

5. Means LW, Walters RE. Sex handedness and asymmetry of hand and foot length. Neuropsychol 1982;20:715-9.

6. Malek AKA, Ahmed AFM, Aziz SSAE, Hamid NAEMAE. Prediction of stature from hand measurements. Forensic Sci Int 1990;46:181-7.

7. Fully G. Une nouvelle méthode de détermination de la taille. Ann Med Legale 1956;35:266-73.

8. Ozaslan A, İscan MY, Ozaslan I, Tugcu H, Koc S. Estimation of stature from body parts. Forensic Sci Int 2003;132(1):40-5.

9. Lundy J. The mathematical versus anatomical methods of stature estimate from long bones. Am J Forensic Med Pathol 1985;6:73-5.

10. Olivier G. Practical anthropology. Springfield: C.C. Thomas; 1969.

11. El Najjar MY, Mc Williams KR. Forensic anthropology: The structure, morphology, and variation of human bone and dentition. Springfield: Charles C. Thomas; 1978.

12. Stewart TD. Essentials of forensic anthropology. Springfield, IL: C.C. Thomas; 1979.

13. Lundy JK. A report on the use of Fully"s anatomical method to estimate stature in military skeletal remains. J Forensic Sci 1988;33:534-9.

14. Ousley S. Should we estimate biological or forensic stature? $J$ Forensic Sci 1995;40:768-73.

15. Maijanen $\mathrm{H}$. Testing anatomical methods for stature estimation on individuals from the W. M. Bass donated skeletal

16. collection. J Forensic Sci 2009;54:746-52.

Lundy JK. Living stature from long limb bones in the South African Negro. S Afr J Sci 1983;79:337-8.

17. Lundy JK. Revised equations for estimating living stature from the long bones of the South African Negro. S Afr J Sci 1987;83:54-5.

18. Dayal MR, Steyn M, Kuykendall KL. Stature estimation from bones of South African whites. S Afr J Sci 2008;104:124e8.

19. Okunribido OO. A survey of hand anthropometry of female rural farm workers in Ibadan, western Nigeria. Ergonomics 2000;43:282-92.

20. Davies BT, Abada A, Benson K, Courtney A, Minto I. A comparison of hand anthropometry of females in three ethnic groups. Ergonomics 1980;23:179-82.

21. Krishan K, Sharma A. Estimation of stature from dimensions of hands and feet in a north Indian population. J Forensic Leg Med 2007;14:327-32.

22. Giles E, Vallandigham PH. Height estimation from foot and shoeprint length. J Forensic Sci 1991;36(4):1134-1151.

23. Kanchan T, Menezes RG, Moudgil R, Kaur R, Kotian MS, Garg RK. Stature estimation from foot dimensions. Forensic Sci Int 2008;179:241-5. 
24. Ozden H, Balci Y, Demiru C, Turgutd A, Ertugrul M. Stature and sex estimate using foot and shoe dimensions. Forensic Sci Int 2005; 147:181-4.

25. Philip TA. Formulae for estimating stature from foot size by regression method. J Ind Acad Forensic Med 1990;12(2):5762.

26. Philip TA. Reconstruction of stature from foot outline and footprint size. J Indian Acad Forensic Med 1989;11:15-20.

27. Ilayperuma I, Nanayakkara BG, Palahepitiya KN. A model for reconstruction of personal stature based on the measurements of foot length. Galle Med J 2008;13:6-9.

28. Jasuja OP, Singh G. Estimation of stature from hand and phalange length. J Indian Acad Forensic Med 2004;26(3):1006.

29. Rastogi $\mathrm{P}$, Nagesh KR, Yoganarasimha K. Estimation of stature from hand dimensions of north and south Indians. Legal Med 2008;10:185-9.
30. Philip TA. Foot size for predicting stature of Males. Ind Acad Forensic Med 1988;27(2);30-9.

31. Rastogi P, Kanchan T, Menezes RG, Yoganarasimha K. Middle finger length - A predictor of stature in the Indian population. Med Sci Law 2009;49(2):123-6.

32. Eveleth PB, Tanner JM. Worldwide variation in human growth. Cambridge: Cambridge University Press; 1976.

33. Malina RM, Little BB, Stern MP, Gaskill SP, Hazuda HP. Ethnic and social class differences in selected anthropometric characteristics of Mexican American and Anglo adults: the San Antonio heart study. Hum Biol 1983;55:867-83.

How to cite: Shetty B, Deepak M, Monteiro FNP, Castelino KP, Xavier AP. Estimation of stature from dimensions of hands and feet in a South Indian Population. IP Int J Forensic Med Toxicol Sci 2020;5(1):14-9. 